\title{
PENGARUH GOOGLE CLASSROOM PADA EFEKTIFITAS PEMBELAJARAN DI UNIVERSITAS ISLAM LAMONGAN
}

\author{
M. Ghofar Rohman ${ }^{1}$, Purnomo Hadi Susilo ${ }^{2}$ \\ Program Studi Teknik Informatika, Universitas Islam Lamongan \\ Email: m.ghofarrohman@unisla.ac.id ${ }^{1}$, purnomo@unisla.ac.id ${ }^{2}$
}

\begin{abstract}
This research the effect of perceived usefulness, perceived convenience and service quality of the google classroom feature on the effectiveness of learning at the Universitas Islam Lamongan partially. The sample of this study used a nonprobability sampling design method using purposive sampling, with a sample size of 120 . The data was collected using a questionnaire with the respondents being lecturers and students of the Islamic University of Lamongan. This study uses multiple linear regression data analysis techniques, namely by using the $\mathrm{F}$ test and $\mathrm{t}$ test. The results of this study indicate that perceived usefulness and quality of service features have a significant effect on learning effectiveness with $t$ count $<0.005$, perceived convenience has no significant effect on learning effectiveness by using t-test. Based on the results of the $\mathrm{t}$ count $>0.005$, and the relationship between the three independent variables on the dependent variable, there is a strong relationship between learning effectiveness and perceived usefulness and Service Quality of Usage Features, that is. The better the perceived usefulness and service quality of using features, the learning effectiveness will also be better.
\end{abstract}

Keywords: E learning; Google classroom; Learning effectiveness

\begin{abstract}
ABSTRAK
Penelitian ini bertujuan untuk mengetahui pengaruh Persepsi Kemanfaatan, Persepsi kemudahan dan kualitas layanan fitur google classroom terhadap efektifitas pembelajaran di Universitas Islam Lamongan secara parsial. Sample penelitian ini mengunakan metode nonprobability sampling design dengan menggunakan purposive sampling, dengan jumlah sampel 120. Pengumpulan data menggunakan angket dengan responden adalah dosen dan mahasiswa Universitas Islam Lamongan. Penelitian ini menggunakan teknik analisis data regresi linier berganda, yaitu dengan menggunakan uji $\mathrm{F}$ dan uji t. Hasil dari penelitian ini menunjukkan bahwa Persepsi kemanfaatan dan Kualitas fitur pelayanan berpengaruh secara signifikan terhadap efektifitas pembelajaran dengan $t$ hitung $<0,005$, Persepsi kemudahan berpengaruh secara tidak signifikan terhadap efektifitas pembelajaran dilakukan dengan pengujian t-test. Berdasarkan hasil dari t hitung yang $>0,005$, dan hubungan antara ketiga variabel independen terhadap variabel dependen yang terjadi hubungan yang kuat adalah antara efektifitas pembelajaran dengan persepsi kemanfaatan dan Kualitas Layanan Fitur Penggunaan, artinya. Semakin baik Persepsi Kemanfaatan dan Kualitas Layanan Fitur Penggunaan maka efektifitas pembelajaran juga akan semakin baik. Kata Kunci: E learning, Google classroom, Efektifitas pembelajaran.
\end{abstract}

\section{PENDAHULUAN}

Perkembangan dari teknologi informasi dan komunikasi yang sangat pesat menimbulkan efek terjadinya evolusi teknologi yang hampir dapat mengubah tatanan kehidupan manusia.
Hal tersebut disebabkan oleh anggapan bahwa dengan adanya teknologi yang semakin canggih maka akan menjadikan pekerjaan lebih mudah, praktis dan efisien dalam pengerjaannya.

Teknologi cyber merupakan istilah 
umum yang digunakan dalam teori pendidikan untuk menggambarkan pembelajaran dalam bentuk fisik maupun tidak di era revolusi industri 4.0 atau dikenal dengan pendidikan 4.0. Hal ini menunjukan bahwa dunia pendidikan juga tak luput dari kehidupan manusia yang mengalami perkembangan. Terdapat banyak sekali perubahan yang terjadi pada era perkembangan perkembangan teknologi informasi dan komunikasi pada saat sekarang ini, sehingga proses pembelajaran menjadi lebih kekinian dan mutakhir. Hermita, N., Ningsih, H. S., Alim, J. A., Alpusari, M., Putra, Z. H., \& Wijaya, T. T. (2020) pada menelitianya menunjukkan bahwa bahwa komik IPA layak dan dapat digunakan oleh siswa sebagai bahan ajar pembelajaran. Sedangkan penelitian ini merekomendasikan agar penelitian selanjutnya dapat melakukan penelitian untuk menguji keefektifan belajar siswa dengan menggunakan komik IPA, dan Wijaya, T. T., Ying, Z., Purnama, A., \& Hermita, N. (2020) menjelaskan bahwa pembelajaran online di masa pandemi virus corona ini kurang efektif. Minat belajar siswa terhadap pembelajaran online juga rendah.

Perubahan dari metode pembelajaran konvensional melalui metode ceramah di depan kelas berganti dengan pembelajaran yang memanfaatkan fasilitas seperti e-mail, aplikasi android melalui gawai, multimedia interaktif, dan lain-lain. Sehingga hal tersebut menandakan bahwa paradigma pembelajaran telah bergeser dari pembelajaran konvensional menuju pembelajaran era digital. Wijaya, T. T., Jianlan, T., \& Purnama, A. (2020) menjelaskan bahwa penggunaan perangkat lunak matematika dinamis Hawgent pada pembelajaran matematika telah terbukti dapat meningkatkan kreativitas siswa dan juga dapat membantu guru dalam menjelaskan suatu konsep matematika yang abstrak sehingga lebih mudah dipahami oleh siswa. Dan Zhang, L., Zhou, Y., \& Wijaya, T. T. (2020) dalam penelitianya menjelaskan bahwa kemampuan pemecahan masalah siswa yang menggunakan media pembelajaran interaktif lebih baik daripada kemampuan peemcahan masalah siswa yang tidak menggunakan media pembelajaran interaktif.

Seiring dengan hal tersebut, peran media pembelajaran dinilai sangat penting dan berpengaruh dalam pengembangan model pembelajaran masa kini. Yakni dengan memanfaatkan media yang semakin berkembang seharusnya juga dapat membawa model pembelajaran semakin berkembang dan tidak terkesan monoton sehingga dapat meningkatkan minat belajar dan kemandirian belajar mahasiswa.

Kini mulai bermunculan media yang mendukung pembelajaran berupa aplikasi dan program berbasis online serta menawarkan berbagai fitur dan fasilitas berkaitan dengan pembelajaran, diantaranya yakni Google Classroom. Media tersebut merupakan salah satu media IT yang menawarkan layanan online gratis untuk sekolah, non-profit, dan siapapun yang memiliki akun google. Dengan adanya aplikasi atau program yang mendukung pembelajaran seperti di atas, seharusnya dapat menjadikan pembelajaran di era-digital ini dapat berkembang. Akan tetapi, tidak sedikit tenaga pendidik yang berkenan untuk berusaha memanfaatkan teknologi tersebut. Meskipun masih terdapat beberapa hambatan dalam penerapannya seperti membutuhkan koneksi atau jaringan yang baik, membutuhkan perangkat yang mendukung, serta pengetahuan tentang penggunaan aplikasi atau program tersebut.

Contohkanlah Google Classroom, sebagai salah satu media pembelajaran masa kini yang tengah dikembangkan aplikasi tersebut mendukung berbagai model pembelajaran yang diyakini dapat sangat membantu proses pembelajaran 
agar lebih efektif dan efisien. Selain itu aplikasi ini cukup lengkap dan sederhana dengan fitur-fiturnya yang juga senantiasa dikembangkan dan dikhususkan untuk pembelajaran sehingga tidak khawatir akan terjadi penyalahgunaan oleh peserta didik.

Universitas Islam Lamongan telah menerapkan pembelajaran berbasis online dalam proses pembelajaranya, utamanya selama masa pandemic covid19. Dosen-dosen banyak yang memanfaatkan teknologi tersebut sebagai media dalam proses pembelajaran. Salah satu aplikasi yang digunakan adalah Google Classroom.

Penggunaan Google Classroom menjadi alternatif yang dipilih dosen untuk berinteraksi dengan mahasiswa sehingga pembelajaran dapat dilakukan tanpa adanya halangan ruang dan waktu. Bahkan dengan aplikasi tersebut dosen dapat membuat kelas virtual kapanpun dan dimanapun. Dengan penggunaan media tesebut dapat menjadikan proses pembelajaran lebih efektif dan efisien.

Sehingga kegiatan perkuliahan tetap bisa berjalan dengan baik meskipun dosen tidak bisa hadir dan memberikan perkuliahan di dalam kelas. Mengingat kegiatan perkuliahan berbeda dengan pembelajaran di sekolah. Mahasiswa diarahkan untuk belajar secara mandiri dan aktif mencari berbagai sumber belajar mereka. Tidak menjadikan dosen sebagai sumber utama layaknya peran guru di sekolah.

Penggunaan Google Classroom dalam pembelajaran diharapkan mampu meningkatkan efektifitas pembelajaran di Universitas Islam Lamongan. Dengan penggunaan aplikasi Google Classroom dalam kegiatan pembelajaran, dosen dapat mengelola materi pembelajaran dalam kelas digital dan bertukar informasi serta diskusi dengan mahasiswa yang menjadi peserta didik pada mata kuliahnya. Sehingga memungkinkan dosen untuk mendorong mahasiswa agar lebih aktif dan interaktif baik saat bertatap langsung di kelas maupun saat tidak bertatap muka secara langsung.

Tujuan pada penelitian ini adalah untuk mengetahui pengaruh persepsi kemudahan, persepsi kemanfaatan, dan kualitas fitur layanan penggunaan terhadap efektivitas pembelajaran di Universitas Islam Lamongan.

Wijaya (2016), pada penelitian ini menunjukan bahwa persepsi penggunaan yang mudah dan persepsi kegunaan yang dirasakan secara positif mempengaruhi penggunaan aplikasi Google Classroom pada proses pembelajaran.

Sedangkan pada penelitian Afrianti (2018) menunjukan bahwa tidak ada pengaruh yang signifikan dari kemudahan dan Harapan mahasiswa terhadap penggunaan Google Classroom dalam menunjang pembelajaran Akuntansi. Sedangkan untuk performa dari aplikasi Google Classroom dan pengaruh sosial terhadap penggunaan Google Classroom terdapat pengaruh yang signifikan

Wijaya, T. T., Ying, Z., \& Suan, L. (2020) pada penelitianya yang bertujuan untuk membandingkan self-regulated learning antara siswa laki-laki dan siswa perempuan pada masa pandemik COVID-19 di Indonesia, pada hasil penelitianya menunjukkan bahwa selfregulated learning siswa perempuan lebih baik dibandingkan siswa laki-laki pada pandemi COVID-19.

Pandey, D., Ogunmola, G. A., Enbeyle, W., Abdullahi, M., Pandey, B. K., \& Pramanik, S. (2021). Menjelaskan bahwa siswa lebih memilih menggunakan sarana pembelajaran multimedia, penelitian ini memberikan rekomendasi untuk menggunakan metode pembelejaran online, tetapi akhirnya, studi menyimpulkan bahwa kepuasan dengan studi online signifikan dalam model atau sikap terhadap penyampaian kelas online selama lockdown pandemi COVID-19 pada tingkat signifikansi 5\%. 
Wijaya, T. T. (2021) pada penelitianya menjelaskan bahwa siswa mempunyai sikap belajar yang baik terhadap pembelajaran dengan video. Siswa merasa bahwa proses pembelajaran dengan video sangat menarik namun efektif karena siswa mampu memahami konsep materi yang diajarkan.

\section{METODOLOGI PENELITIAN}

Data yang dipergunakan dalam penelitian adalah data primer yang diperoleh dengan membagikan kuesioner kepada Dosen dan Mahasiswa. Pada penelitian ini yang dijadikan unit yang tersebar di masing-masing semester pada program studi teknik informatika.

Menurut Sekaran dan Bougie (2017) Sampel adalah sebagian dari populasi. Metode yang dilakukan untuk menentukan sample pada penelitian ini adalah menggunakan metode Nonprobability Sampling Design dengan menggunakan purposive sampling. Jumlah minimal sampel adalah 5 kali dari jumlah indikatornya (jumlah item pernyataan atau pertanyaan dalam kuisoner) (Hairy dkk: 2006).

Table 1 Coeficients ${ }^{\text {a }}$ (Collinearity Statistics) karena jumlah indikator pada penelitian ini sebanyak 20 pernyataan maka jumlah minimal sampelnya 100, sedangkan yang digunakan sebanyak 120. Kriteria pada penelitian ini adalah Mahasiswa dan Dosen Universitas Islam Lamongan yang berstatus aktif dan menggunakan Google Classroom

\section{HASIL DAN PEMBAHASAN}

Analisis data dengan menggunakan Regresi Linier Berganda, Regresi linier berganda digunakan untuk melihat pengaruh antara variabel bebas: Persepsi Kemanfaatan (X1), Persepsi Kemudahan (X2), Kualitas Layanan Fitur Penggunaan (X3), dengan variabel terikat: Efektifitas Pembelajaran menggunakan Google Classroom (Y).

Hasil analisa melalui program IBM SPSS statistics sebagai berikut:

\section{Model Regresi Linier dan Pengujian Asumsi Klasik}

a. Multikolinieritas

Hasil dari uji multikolinieritas dapat dilihat pada tabel Coefficients ${ }^{\mathrm{a}}$ berikut:

\section{Coefficients $^{\mathrm{a}}$}

\begin{tabular}{|c|c|c|c|c|c|c|c|}
\hline \multirow[b]{2}{*}{ Model } & \multicolumn{2}{|c|}{$\begin{array}{l}\text { Unstandardized } \\
\text { Coefficients }\end{array}$} & \multirow{2}{*}{$\begin{array}{l}\text { Standardized } \\
\text { Coefficients } \\
\text { Beta }\end{array}$} & \multirow[b]{2}{*}{$\mathrm{T}$} & \multirow[b]{2}{*}{ Sig. } & \multicolumn{2}{|c|}{$\begin{array}{l}\text { Collinearity } \\
\text { Statistics }\end{array}$} \\
\hline & B & Std. Error & & & & Tolerance & VIF \\
\hline 1 (Constant) & 1,987 &, 761 & & 2,612 &, 010 & & \\
\hline $\mathrm{X} 1$ & ,397 & ,068 & ,488 & 5,843 & ,000 & ,433 & 2,311 \\
\hline $\mathrm{X} 2$ &,- 042 & ,065 &,- 061 &,- 637 &, 525 & ,329 & 3,044 \\
\hline $\mathrm{X} 3$ & ,327 & ,081 & ,426 & 4,050 & ,000 & ,272 & 3,674 \\
\hline
\end{tabular}

a. Dependent Variable: Y

Dari hasil analisis data diatas telah diperoleh bahwa nilai VIF pada kolom Colliniearity Statistics untuk Persepsi Kemanfaatan (X1) $=2,311$, Persepsi Kemudahan (X2) $=3,044$, Kualitas Layanan Fitur Penggunaan $(\mathrm{X} 3)=3,674$, sedangkan untuk nilai tolerance Persepsi Kemanfaatan (X1) $=0,433$, Persepsi Kemudahan (X2) $=0,329$, Kualitas Layanan Fitur Penggunaan $(X 3)=0,272$. Dari hasil diatas nilai VIF untuk ketiga variabel tidak ada nilai yang lebih besar dari 10 , sehingga dalam hal ini dapat dikatakan 
bahwa tidak terjadi multikolinieritas pada ketiga variabel bebas tersebut. Berdasarkan asumsi klasik regresi linier, maka model regresi linier yang dapat dikatakan baik adalah terbebas dari adanya multikolinieritas. Dengan demikian, model yang didapatkan diatas telah terbebas dari adanya multikolinieritas.

\section{b. Autokorelasi \\ Data yang digunakan untuk mengestimasi model regresi linier merupakan data time series maka diperlukan adanya uji asumsi terbebas dari autokorelasi. Hasil uji autokorelasi, dapat dilihat pada tabel Model Summary $^{\text {b }}$ berikut:}

Tabel 2 Model Summary (Durbin-Watson) Model Summary ${ }^{b}$

\begin{tabular}{|c|c|c|c|c|c|}
\hline Model & $\mathrm{R}$ & R Square & $\begin{array}{l}\text { Adjusted } \\
\text { Square }\end{array}$ & $\begin{array}{l}\text { R Std. Error of } \\
\text { the Estimate }\end{array}$ & Durbin-Watson \\
\hline 1 &, $806^{\mathrm{a}}$ &, 650 & ,641 & 1,492 & 1,966 \\
\hline
\end{tabular}

b. Dependent Variable: Y

Pada Nilai Durbin-Watson (DW hitung) yang tertera output hasil analisis dengan SPSS sebesar 1.966. Nilai DW hitung sebesar 1.966 lebih besar dari 1.5274 dan lebih kecil dari 2.4726 yang artinya berada pada daerah tidak ada autokorelasi. Sehingga dapat disimpulkan bahwa dalam model regresi linier ini, yaitu variabel Persepsi Kemanfaatan (X1), Persepsi Kemudahan (X2) dan Kualitas Layanan Fitur Penggunaan (X3) tidak terjadi autokorelasi

\section{c. Heteroskedastisitas}

Pengujian heteroskedastisitas dilakukan adalah dengan membuat Scatterplot (alur sebaran) antara residual dan nilai prediksi dari variabel terikat yang telah distandarisasi. Untuk hasil uji heteroskedastisitas dapat dilihat pada gambar Scatterplot di bawah ini:

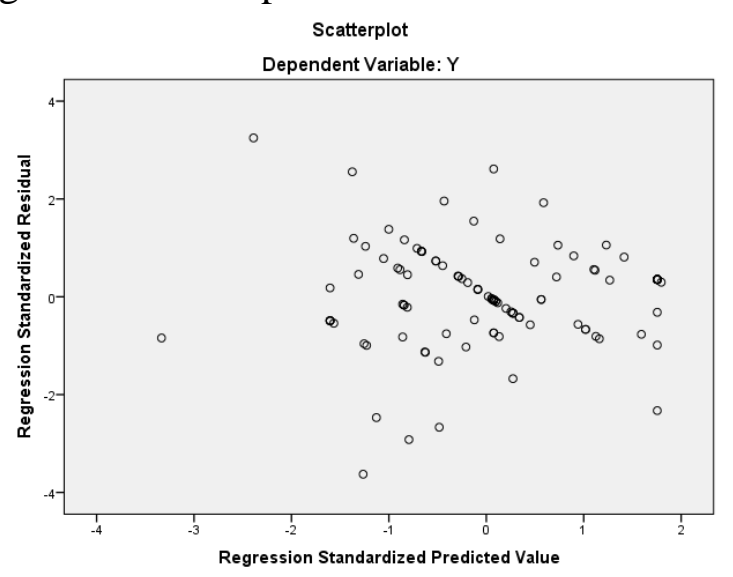

\section{Gambar 1. Scatter Plot}

Dari gambar 1 scatterplot di atas terlihat bahwa sebaran titik-titik pada gambar tidak membentuk suatu pola atau suatu alur tertentu, sehingga dari hal ini dapat disimpulkan bahawa pada hasil analisa data tidak terjadi heteroskedastisitas atau dengan kata lain telah terjadi yang namanya homoskedastisitas. Asumsi klasik tentang heteroskedastisitas dalam model ini terpenuhi, yaitu terbebas dari adanya heteroskedastisitas.

\section{d. Normalitas}

Hasil uji normalitas dapat dilihat dari gambar Normal P-P Plot pada gambar di bawah ini. 
Jurnal PTK dan Pendidikan

Vol. 7, No. 1, Januari - Juni 2021 (67-76)

Normal P-P Plot of Regression Standardized Residual

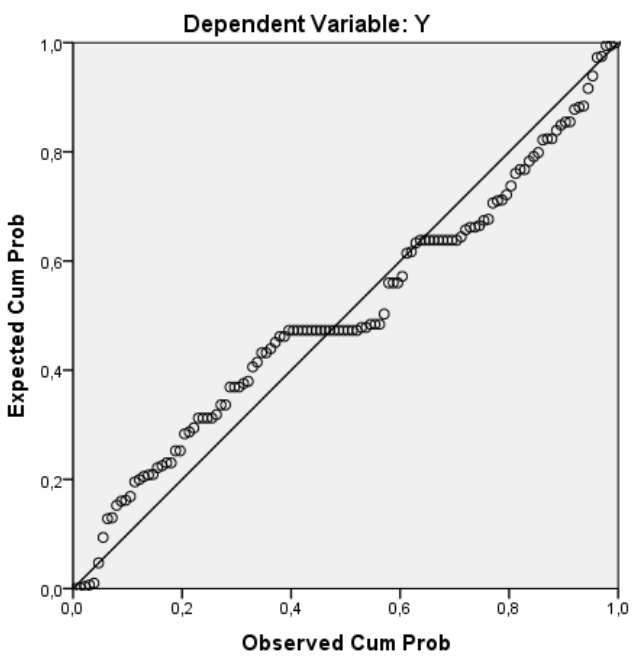

Gambar 2. Normal P-P Plot
M. Ghofar Rohman, Purnomo Hadi Susilo

terdistribusi normal. Hasil ini sesuai dengan asumsi klasik dari regresi linier.

\section{Uji Kelayakan Model}

a. Uji Kehandalan Model (Uji F)

Pada hasil analysis dengan uji $\mathrm{F}$ dapat dilihat pada tabel ANOVA ${ }^{\text {a }}$ di bawah ini.

Sebaran titik-titik pada gambar 2 Normal P-P Plot relatif semua titik mendekati garis lurus, sehingga dari hal ini dapat disimpulkan bahwa (data) residual

Tabel 3 ANOVA $^{\text {a }}$ (Sig. F Hitung)

ANOVA $^{\mathrm{a}}$

\begin{tabular}{|c|c|c|c|c|c|c|}
\hline Model & & $\begin{array}{l}\text { Sum } \\
\text { Squares }\end{array}$ & Df & Mean Square & $\mathrm{F}$ & Sig. \\
\hline \multirow[t]{3}{*}{1} & Regression & 479,500 & 3 & 159,833 & 71,807 &, $000^{b}$ \\
\hline & Residual & 258,200 & 116 & 2,226 & & \\
\hline & Total & 737,700 & 119 & & & \\
\hline
\end{tabular}

a. Dependent Variable: Y

b. Predictors: (Constant), X3, X1, X2

Dapat dilihat pada table 3 diatas, dimana nilai prob. F hitung ( sig.) pada tabel di atas nilainya 0,000 yang mana hal ini lebih kecil dari tingkat signifikansi 0,05 sehingga dapat disimpulkan bahwa model regresi linier diestimasi layak digunakan untuk menjelaskan pengaruh penggunaan google classroom terhadap efektifitas Pembelajaran (Y) ditinjau dari

Tabel 4 Coeficient ${ }^{\mathrm{a}}$ (Sig.)

Coefficients $^{\text {a }}$

\begin{tabular}{|c|c|c|c|c|c|c|c|c|}
\hline \multirow[b]{2}{*}{ Model } & & \multicolumn{2}{|c|}{$\begin{array}{l}\text { Unstandardized } \\
\text { Coefficients }\end{array}$} & \multirow{2}{*}{$\begin{array}{l}\text { Standardized } \\
\text { Coefficients } \\
\text { Beta }\end{array}$} & \multirow[b]{2}{*}{$\mathrm{T}$} & \multirow[b]{2}{*}{ Sig. } & \multicolumn{2}{|c|}{ Collinearity Statistics } \\
\hline & & $\mathrm{B}$ & Std. Error & & & & Tolerance & VIF \\
\hline \multirow[t]{2}{*}{1} & (Constant) & 1,987 & ,761 & & 2,612 & ,010 & & \\
\hline & $\mathrm{X} 1$ & ,397 & ,068 & ,488 & 5,843 &, 000 & ,433 & 2,311 \\
\hline
\end{tabular}

Persepsi Kemanfaatan (X1), Persepsi Kemudahan (X2), dan Kualitas Layanan Fitur Penggunaan (X3).

\section{Uji Koefisien Regresi (Uji t)}

Hasil pengujian dapat dilihat pada tabel Coefficients $^{\mathbf{a}}$ seperti pada gambar di bawah ini: 


\begin{tabular}{llllllll}
\hline $\mathrm{X} 2$ &,- 042 &, 065 &,- 061 &,- 637 &, 525 &, 329 & 3,044 \\
$\mathrm{X} 3$ &, 327 &, 081 &, 426 & 4,050 &, 000 &, 272 & 3,674 \\
\hline
\end{tabular}

a. Dependent Variable: Y

Dimana pada tabel coefisien $^{\mathrm{a}}$ diatas didapatkan bahwa nilai prob. $\mathrm{t}$ hitung dari variabel bebas Persepsi Kemanfaatan (X1) dengan nilai sebesar 0.000, dan Kualitas Layanan Fitur Penggunaan (X3) dengan nilai sebesar 0.000 yang mana nilainya lebih kecil dari 0,05 sehingga variabel bebas Persepsi Kemanfaatan (X1), dan Kualitas Layanan Fitur Penggunaan (X3) dikatakan berpengaruh signifikan terhadap variabel terikat Efektifitas Pembelajaran menggunakan Google Classroom (Y).

Sedangkan untuk nilai prob. $\mathrm{t}$ hitung dari variabel bebas Persepsi Kemudahan (X2) yang didapatkan sebesar 0.525, yang mana lebih besar dari 0,05 sehingga variabel bebas Persepsi Kemudahan (X2) sehingga hal ini menunjukkan bahwa tidak berpengaruh signifikan terhadap variabel terikat
Efektifitas Pembelajaran menggunakan Google Classroom (Y).

Dikarenakan nilai prob. $\mathrm{t}$ hitung dengan nilai $(0,000)$ yang lebih kecil dari 0,05 sehingga hal ini menunjukkan bahwa variabel bebas Persepsi Kemanfaatan (X1), dan Kualitas Layanan Fitur Penggunaan (X3) berpengaruh signifikan terhadap variabel terikat Efektifitas Pembelajaran menggunakan Google Classroom (Y) yaitu pada alpha $5 \%$ atau dengan kata lain dapat disimpulkan bahwa, Persepsi Kemanfaatan (X1), dan Kualitas Layanan Fitur Penggunaan (X3) berpengaruh signifikan terhadap Efektifitas Pembelajaran pada taraf keyakinan $95 \%$.

\section{b. Koefisien Determinasi}

Hasil pengujian dapat dilihat pada tabel model summary ${ }^{\mathbf{b}}$ seperti pada gambar di bawah ini:

\begin{tabular}{|c|c|c|c|c|c|}
\hline \multicolumn{6}{|c|}{$\begin{array}{c}\text { Tabel } 5 \text { Model Summary (R-Square) } \\
\text { Model Summary }^{\text {bod }}\end{array}$} \\
\hline Model & $\mathrm{R}$ & R Square & $\begin{array}{l}\text { Adjusted } \\
\text { Square }\end{array}$ & $\begin{array}{l}\mathrm{R} \text { Std. Error of the } \\
\text { Estimate }\end{array}$ & Durbin-Watson \\
\hline 1 &, $806^{\mathrm{a}}$ & ,650 & ,641 & 1,492 & 1,966 \\
\hline
\end{tabular}

\section{Jika dilihat dari nilai R-Square yang nilainya besarnya 0,650 menunjukkan bahwa proporsi pengaruh variabel bebas dari Persepsi Kemanfaatan (X1), Persepsi Kemudahan (X2), Kualitas Layanan Fitur Pembelajaran Google classroom (X3), terhadap Efektifitas Pembelajaran menggunakan Google Classroom (Y) adalah sebesar $65.00 \%$. Artinya, Persepsi Kemanfaatan, Persepsi Kemudahan, dan Kualitas Layanan Fitur Pembelajaran Google classroom memiliki}

proporsi pengaruh terhadap Efektifitas Pembelajaran menggunakan Google Classroom (Y) sebesar $65.00 \%$ sedangkan sisanya $35.00 \%$ dipengaruhi oleh variabel lain yang tidak ada didalam model regresi linier.

\section{Interpretasi Model}

Sedangkan untuk model (persamaan) regresi linier berganda dapat diperoleh dari tabel coefficients ${ }^{\mathbf{a}}$ di bawah ini: 


\begin{tabular}{|c|c|c|c|c|c|c|c|}
\hline \multirow[b]{2}{*}{ Model } & \multicolumn{2}{|c|}{$\begin{array}{l}\text { Unstandardized } \\
\text { Coefficients } \\
\end{array}$} & \multirow{2}{*}{$\begin{array}{l}\text { Standardized } \\
\text { Coefficients }\end{array}$} & \multirow[b]{2}{*}{$\mathrm{T}$} & \multirow[b]{2}{*}{ Sig. } & \multicolumn{2}{|c|}{$\begin{array}{l}\text { Collinearity } \\
\text { Statistics }\end{array}$} \\
\hline & $\mathrm{B}$ & Std. Error & & & & Tolerance & VIF \\
\hline 1 (Constant) & 1,987 &, 761 & & 2,612 &, 010 & & \\
\hline $\mathrm{X} 1$ & ,397, & 068, & 488, & 5,843 & , 000 & 433, & 2,311 \\
\hline $\mathrm{X} 2$ &,- 042 & 065, &,- 061 &,- 637 & ,525 & ,329 & 3,044 \\
\hline X3 &, 327 & ,081 & ,426 & 4,050 & ,000 & ,272 & 3,674 \\
\hline
\end{tabular}

a. Dependent Variable: $\mathrm{Y}$

Sehingga diperoleh model (persamaan) regresi linier berganda yang telah diestimasi sebagai berikut:

$$
\mathrm{Y}=1.987+0.397 \mathrm{X} 1-0.42 \mathrm{X} 2+0.327 \mathrm{X} 3
$$

Koefisien regresi Persepsi Kemanfaatan (X1) dengan nilai positif artinya pada saat nilai Persepsi Kemanfaatan baik maka Efektifitas Pembelajaran menggunakan Google Classroom (Y) juga akan baik. Begitu pula sebaliknya, pada saat Persepsi Kemanfaatan nilainya kurang baik maka Efektifitas Pembelajaran juga akan turun nilainya.

Koefisien regresi Persepsi Kemudahan (X2) mendapat nilai negatif artinya Persepsi Kemudahan tidak berpengaruh signifikan terhadap Efektifitas Pembelajaran menggunakan Google Classroom (Y).

Koefisien regresi Kualitas Layanan Fitur Pembelajaran Google classroom (X3) mendapatkan nilai positif artinya pada saat nilai Persepsi Kemanfaatan baik maka nilai Efektifitas Pembelajaran menggunakan Google Classroom (Y) juga akan baik. Begitu pula sebaliknya, pada saat nilai Kualitas Layanan Fitur Pembelajaran Google classroom kurang baik maka Efektifitas Pembelajaran juga akan turun.

\section{KESIMPULAN DAN SARAN Kesimpulan}

Berdasarkan hasil penelitian dan analisis yang telah dilakukan kepada dosen dan mahasiswa Universitas Islam Lamongan, Maka dapat disimpulkan bahwa Persepsi kemanfaatan (X1) berpengaruh secara signifikan terhadap efektifitas pembelajaran (Y). Berdasarkan hasil dari t hitung yang didapatkan < 0,005, maka dapat dikatakan bahwa pengaruh Persepsi kemanfaatan (X1) dan Kualitas fitur pelayanan (X3) terhadap efektifitas pembelajaran (Y) adalah signifikan pada alpha 5\%. Sedangkan Persepsi kemudahan (X2) berpengaruh secara signifikan terhadap efektifitas pembelajaran (Y) dilakukan dengan pengujian t-test. Hal ini berdasarkan dari hasil t hitung yang $>0,005$, maka hal ini menunjukkan bahwa pengaruh persepsi kemudahan (X2) terhadap efektifitas pembelajaran (Y) adalah tidak signifikan, dan Hubungan antara ketiga variabel independen (X1), (X2), dan (X3) terhadap variabel dependen $(\mathrm{Y})$, terjadi hubungan yang kuat adalah pada efektifitas pembelajaran dengan persepsi kemanfaatan dan Kualitas Layanan Fitur Penggunaan, artinya. Semakin baik Persepsi Kemanfaatan (X1) dan Kualitas Layanan Fitur Penggunaan (X3) maka efektifitas pembelajaran juga semakin baik.

\section{Saran}

Berdasarkan kesimpulan di atas, dapat dikemukakan saran bahwa: pada penelitian ini focus pada pembelajaran di program studi teknik informatika, sehingga saran untuk penelitian selanjutnya dapat dilakukan pada tingkat yang lebih luas, dan untuk variabel yang digunakan juga dapat dikembangkan lagi.

\section{DAFTAR PUSTAKA}


Afrianti, W. E. (2018). Penerapam Google Classroom Dalam Pembelajaran Akuntansi ( Studi Pada Program Studi Akuntansi Universitas Islam Indonesia )

Ghozali, I. (2013). Aplikasi Analisis dengan Program SPSS. Semarang: Badan Penerbit Universitas Diponegoro.

Hermita, N., Ningsih, H. S., Alim, J. A., Alpusari, M., Putra, Z. H., \& Wijaya, T. T. (2020). Developing Science Comics for Elementary School Students on Animal Diversity. Solid State Technology, 63(1s).

Pandey, D., Ogunmola, G. A., Enbeyle, W., Abdullahi, M., Pandey, B. K., \& Pramanik, S. (2021). COVID-19: A Framework for Effective Delivering of Online Classes During Lockdown. Human Arenas, (0123456789).

https://doi.org/10.1007/s42087020-00175-x

Priambodo, S., \& Prabawani, B. (2016). Pengaruh Persepsi Manfaat, Persepsi Kemudahan Penggunan, dan Persepsi Risiko Terhadap Minat Menggunakan Layanan Uang Elektronik (Studi Kasus Pada Masyarakat di Kota Semarang). Jurnal Ilmu Administrasi Bisnis, $5(2), 1-9$.

Sekaran, Uma, and Roger Bougie. (2017). Metode Penelitian Untuk Bisnis: Pendekatan Pengembangan keahlian, Buku II (6thed ed.). Jakarta: Salemba Empat.

Wijaya, A. (2016). Analysis of Factors Affecting The Use of Google Classroom to Support Lectures. The 5th International Conference on Information ...,(February), 1920. Retrieved from http://eprints.binadarma.ac.id/2777/

Wijaya, T. T. (2021). How chinese students learn mathematics during the coronavirus pandemic. International Journal of Educational Research and Innovation (IJERI), 15, $\quad 1-16$. https://doi.org/https://doi.org/10.46 661/ijeri.4950

Wijaya, T. T. (2021). How chinese students learn mathematics during the coronavirus pandemic. International Journal of Educational Research and Innovation (IJERI), 15 , $\quad 1-16$. https://doi.org/https://doi.org/10.46 661/ijeri.4950

Wijaya, T. T., Jianlan, T., \& Purnama, A. (2020). Developing an Interactive Mathematical Learning Media Based on the TPACK Framework Using the Hawgent Dynamic Mathematics Software. Emerging Technologies in Computing, 318328. https://doi.org/10.1007/978-3030-60036-5

Wijaya, T. T., Ying, Z., \& Suan, L. (2020). Gender and Self-regulated Learning During COVID-19 Pandemic in Indonesia. Jurnal Basicedu, 4(3), 725-732. https://doi.org/10.31004/basicedu.v $4 \mathrm{i} 3.422$.

Wijaya, T. T., Ying, Z., Purnama, A., \& Hermita, N. (2020). Indonesian students' learning attitude towards online learning during the coronavirus pandemic. Psychology, Evaluation, and Technology in Educational Research, 3(1), 17-25. https://doi.org/10.33292/petier.v3i1 .56

Yulita, H. (2014). Faktor-Faktor Yang Mempengaruhi Efektivitas Dan Motivasi Mahasiswa Dalam Menggunakan Metode Pembelajaran E-learning, 10(1), 115.

Zhang, L., Zhou, Y., \& Wijaya, T. T. 
Jurnal PTK dan Pendidikan

Vol. 7, No. 1, Januari - Juni 2021 (67-76)

(2020). Hawgent dynamic mathematics software to improve problem-solving ability in teaching triangles. Journal of Physics:

Conference Series, 1663(1). https://doi.org/10.1088/1742-

6596/1663/1/012069
M. Ghofar Rohman, Purnomo Hadi Susilo 